
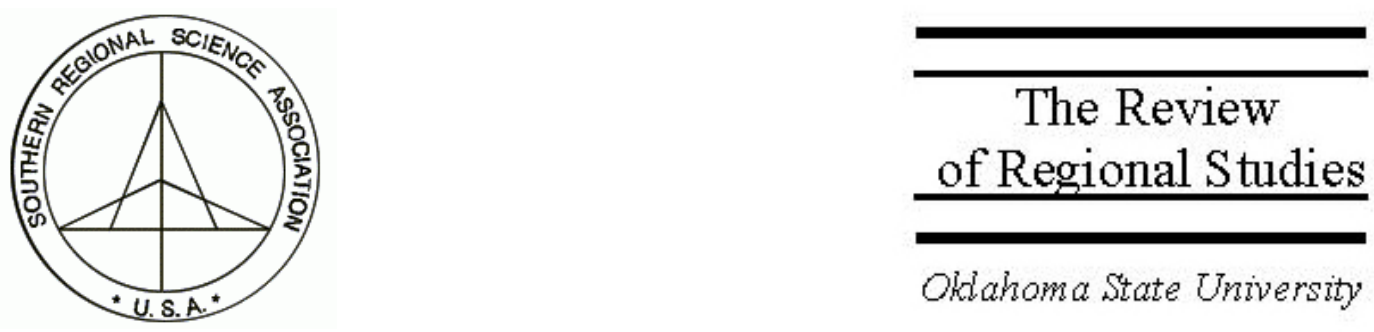

\title{
Trade Liberalization and Location: Empirical Evidence for Mexican Manufacturing Industries
}

\author{
Jacob A. Jordaan
}

Faculty of Economics and Business Administration, Free University of Amsterdam, De Boelelaan 1105, 1081 HV Amsterdam, The Netherlands, e-mail: jjordaan@feweb.vu.nl

\section{Javier Sanchez-Reaza}

Centro de Investigación y Docencia Económicas (CIDE), Carr. México-Toluca 3655, Col.Lomas de Sta.Fé, México, DF 01210, México, e-mail: javier.sanchez@cide.edu

\begin{abstract}
In this paper, we provide evidence based on New Economic Geography Models and estimate the statistical effects of second nature advantages to shed some light on the locational transformation of the manufacturing sector in Mexico. Changes in regional industry shares and regional wages during trade liberalization show that the border states have gained at the expense of the old manufacturing belt in Mexico City. Furthermore, the statistical evidence indicates that that the relevant market has shifted from Mexico City to the USA. However, the relation between trade liberalization and industry location is subject to a considerable level of industry heterogeneity, suggesting the co-existence of processes of regional convergence and divergence.
\end{abstract}

Keywords: Mexico; New economic geography; Trade liberalization; Agglomeration; Externalities 


\section{INTRODUCTION}

Recent theoretical work on the relation between trade and location shows that this relation may be less clear cut than previously thought. New Economic Geography (NEG) models of the type initiated by Krugman (1991a; 1991b) and followed by Krugman and Venables (1995); Venables (1996); and Fujita, Krugman, and Venables (1999) have produced a straightforward prediction of the relation between trade costs and location. Decreasing trade costs lead to the agglomeration of economic activity as firms are able to reap the benefits from concentration of production and minimization of trade costs by locating in proximity to the market. However, more recent contributions show that the relation between trade costs and location is less straightforward in cases where at least one of the countries is modeled to have two regions.

Adapting the approach of Krugman (1991a, b) to analyze cases where changing trade costs between two countries affect location behavior within the two-region country, Krugman and Elizondo (1996) offer a model inspired by the existence of the urban giant Mexico City. They find that decreasing international trade costs can lead to a dispersion of economic activity within a country. In contrast, however, decreasing international trade costs have also been found to promote intra-country agglomeration of economic activity in the multi-regional country, as shown by Alonso-Villar (1999), Monfort and Nicolini (2000), and Crozet and Koenig Soubeyran (2004).

Furthermore, theories on the relation between trade costs and location offer a onedimensional explanation for industry location. In addition to NEG, at least two other alternative theories can be considered when we want to explain industry location behavior (Head and Mayer 2004). One explanation can be found in classical trade theory that links the distribution of industries to the spatial distribution of resource endowments. Simply put, an industry locates in a region that is disproportionately endowed with those factors of production that the industry uses intensively in its production process. Second, urban economics explains agglomeration through the occurrence of productivity effects in the form of place-based externalities. These agglomeration economies form the centripetal force in the process of urbanization.

Several chapters in the recent Handbook of Urban and Regional Economics (2004) contain excellent surveys of the current body of empirical evidence. ${ }^{1}$ These surveys show that all three different location theories are supported by empirical evidence. Having said so, they also reveal that this type of research involves a variety of difficult choices regarding data, model specification, and econometric issues (see especially Combes and Overman, 2004). A further issue is that the surveys reflect that empirical research related to recent NEG models is seriously lacking. These recent models are particularly important as they explicitly include a regional dimension. As the effects of trade liberalization are likely to differ between regions within a country, it is crucial to include

\footnotetext{
${ }^{1}$ See the chapters by Head and Mayer, Combes and Overman on the EU, Fujita et al. for Asia, and Holmes and Stevens for North America. See also Hanson (2001).
} 
this regional dimension. This only reinforces the importance of new empirical research that explores the regional dimension of the relation between trade and industry location.

In this paper, we provide new empirical evidence on the relation between trade and industry location in the republic of Mexico, which represents an empirical setting that resembles cases analyzed by recent theoretical NEG models. Mexico can be pictured as having two main regions in the form of Mexico City and the border area. Furthermore, Mexico has undergone a structural change in its trade strategy from import substitution to export promotion, culminating in the creation of the North American Free Trade Agreement (NAFTA) with the U.S. as main export market. ${ }^{2}$ This sudden and exogenous switch in Mexican trade policy allows us to treat the distribution of industries and changes as the result of a natural experiment in which we can causally link changes in location patterns with trade liberalization.

Our empirical analysis consists of two parts. First, we inspect general trends in employment and wage statistics. In particular, we ask whether Mexico City or the border states have gained during trade liberalization. Growing shares in industry employment and/ or improved relative wages of Mexico City would suggest that trade liberalization stimulates agglomeration (regional divergence), whereas growing employment shares and/or improvements of relative wages of the border states would be in support of a positive relation between trade liberalization and de-agglomeration (regional convergence).

The second part of the empirical analysis statistically disentangles the effects of NEG and externalities, so-called second-nature advantages (Head and Mayer 2004). In addition to establishing whether these second-nature advantages statistically influence the location of industries, the Mexican case also allows us to assess whether the relative importance of these second-nature advantages has changed under trade liberalization. In particular, we are interested in finding out whether trade liberalization has altered the relative importance of the markets in the form of Mexico City and the U.S.

The remainder of the paper is constructed as follows. In Section two we discuss the main location theories in the form of NEG, classical trade theory, and urban economics and review empirical evidence. Section three presents the empirical setting of Mexico. We describe changes in location patterns of manufacturing industries following trade liberalization, focusing on Mexico City and the border states as alternative locations. Furthermore, we look at changes in regional relative wages in the same period, as these can also be taken as indications of shifts in the centripetal forces of Mexico City and the U.S.

In Section four, we discuss our specification of the reduced form model that we use to disentangle the relative contributions of the second-nature advantages. Section five presents the empirical findings. Our main findings are three-fold. First, the pooled

\footnotetext{
${ }^{2}$ According to data from the Mexican ministry of economics, the U.S. was the destination market
} for 88 percent of the total value of Mexican exports in 2004 (http://www.economia-snci.gob.mx). 
estimations confirm the general importance of both markets as location factor as both distance to Mexico City and the U.S. are negatively associated with industry agglomeration. Second, the statistical evidence on the relation between trade liberalization and industry location shows a change in the relative importance of the two markets. During the period of trade liberalization, the estimated coefficient of distance to Mexico City has decreased, whereas the estimated coefficient of distance to the U.S. has become significant and has increased in size. This suggests that trade liberalization favors regional convergence. Having said so, the third main finding is that there is a considerable amount of heterogeneity among industries. We identify three types of industries for which destination markets have different importance as location factors. The finding that Mexico City is the important market for some industries whereas for other industries the U.S. market is also an important destination market suggests that both processes of regional convergence and divergence are at work. Finally, Section 6 summarizes and concludes.

\section{TRADE AND LOCATION OF INDUSTRY}

\subsection{NEG}

The original NEG models initiated by Krugman (1991a, b) explain the location process of an industry in relation to trade (transport) costs. Within a two-country twosector, two-industry framework where the countries have identical initial endowments, the models study how and why the mobile industry may become agglomerated in one of the two countries following a decrease in trade costs between the two countries. From the starting point of high trade costs and equal shares of the mobile industry in both countries, the general finding of these models is that the mobile industry agglomerates through relocation in one of the two regions at intermediate values of transport costs. Intermediate values of trade costs are high enough to constitute an incentive for producers to locate in the country where the industry is agglomerated in order to reap the benefits from scale economies and savings on transport costs. The resulting savings on transport costs allow for the costly export to consumers remaining in the other country.

The central factor that leads to the agglomeration of the industry is proximity to the market. As Head and Mayer (2004, p. 2611) state, the NEG process can be summarized as "...producers and consumers co-locating to exploit plant-level scale economies while minimizing trade costs." In the two-country, two-sector setting, the market can attract workers and firms in two ways. In Krugman (1991a, b) the market attracts firms as it represents the presence of mobile workers in the role of consumers of final products. Workers go to the country that can afford higher wages due to the agglomeration, which starts the cumulative process of attracting more firms, which attracts more workers, etc. In Krugman and Venables (1995) and Venables (1996), the attractive force of the market takes shape in the form of input-output linkages. Firms locate in the agglomeration to be close to input-producing firms, thus minimizing transport costs. This in turn attracts more firms producing inputs for the firms in the agglomeration, again highlighting the cumulative nature of the process. Irrespective of whether the attractive power of the market in relation to trade costs is modeled as a demand for final products (Krugman, 1991) or 
demand for intermediate products (Venables, 1996), the results of these models is that agglomeration in one country occurs when trade costs decrease.

There is a variety of empirical evidence supporting the attraction on firms exercised by the market. ${ }^{3}$ Hanson (2004) is the best example of an empirical estimation of the relation between location and the market as an agglomeration of consumption. Firms agglomerate close to the market to be close to consumers. Workers in the agglomeration benefit from this and achieve higher wages. This means that there should be a negative relation between distance from the agglomeration and the wage level. Hanson (2004) offers empirical evidence for U.S. counties showing that such a spatial wage gradient exists. Estimating both a simplified and an augmented market potential function using Krugman (1991) and Helpman (1998), Hanson finds that wages are positively related to market size and negatively related to distance to the market. Brakman, Garretsen, and van Marrewijk (2001) conduct a similar estimation of spatial wage gradients for Germany and find strong evidence of a similar effect of distance.

An alternative type of empirical evidence assessing NEG predictions comes from estimating the relation between agglomeration and factor inflows. Translating spatially differing factor rewards into productivity differences, sustained regional divergence can be tested by estimating the effect of agglomeration on firm location. An appealing way to do this is to estimate the effect of regional characteristics on the distribution of inward foreign investment, as at a given time new inward FDI can be treated as exogenous to the regional distribution of firms in a country at that time. An example of empirical evidence linking FDI to agglomeration is offered by Coughlin, Terza, and Arromdee (1991), who find that the state-level distribution of FDI in the U.S. is positively associated with the size of local demand, confirming the importance of the market for location. Several recent studies have similarly assessed the effect of agglomeration on FDI location. As long as agglomeration represents the presence of input-output linkages, a positive effect of agglomeration is in support of the attractive force of the market as specified by Venables (1996). Examples of empirical studies that find positive effects of agglomeration variables are Head, Ries, and Swenson $(1995,1999)$ for the U.S.; Crozet and Koenig Soubeyran (2004) for France; and Guimarães, Figueiredo, and Woodward (2000) for Portugal.

Finally, a considerably body of evidence is available from research that regresses indices of geographical concentration on sets of controls that include proxies for central forces in NEG, classical trade theory, and/or agglomeration economies. This type of research produces indirect evidence of the importance of proximity to the main market. An example of this is Amitri $(1997,1998)$, who regresses industry Gini coefficients for a sample of industries of five EU countries on a set of control variables, including proxies for internal scale economies and input-output linkages. The findings show that both

\footnotetext{
${ }^{3}$ We do not aim to provide a full discussion of empirical findings. For this, see the survey by Head and Mayer (2004) and the other sources referred to in footnote 1. We focus here on discussing some important empirical approaches and highlight some noteworthy findings.
} 
proxies are significantly positively related to geographical concentration, thus supporting new trade and new economic geography theories. Similar empirical approaches can be found in Brülhart and Trionfetti (1998) and Kim (1995).

\subsection{Recent NEG models}

Recent NEG models have started to study industry location in a slightly different framework. Instead of assuming that each country consists of one region, they analyze cases where one of the countries (or both countries) consists of two regions. In these cases, the effect of decreasing international trade costs on the process of industry location is much less straightforward.

Krugman and Elizondo (1996) develop a model that argues for the idea that decreasing international trade costs can lead to de-agglomeration. Trying to explain the growth and subsequent decline of the urban giant Mexico City, they develop a model with a tworegion country and a third rest-of-the-world region. Economic activity in the two-region country is mobile between regions within the country, but not internationally. They explain the initial situation of agglomeration of economic activity in the form of Mexico City by the fact that the capital city represented the main market for final and intermediate demand in the period of import substitution. This situation changed when international trade costs decreased following the change in development strategy. Lower international trade costs made the rest of the world a more important market at the expense of the initial agglomeration. Increased trade with the rest of the world lowers the centripetal force of the initial agglomeration while at the same time making the centrifugal power in the form of land rents more problematic.

Under these conditions, relocation to the other region in the country becomes more attractive. As the model indicates, lower values for the international trade parameter make "a less concentrated urban system first possible and then necessary" (Krugman and Elizondo, 1996, p. 149). This positive relation between international trade liberalization and regional convergence in the multi-regional country is also found by Fujita, Krugman, and Venables (1999, chapter 18). Furthermore, using an adapted NEG model incorporating both transport costs (between regions in a country) and trade costs (between the two countries), Behrens et al. (2004) find that trade liberalization can lead to deagglomeration.

In contrast, other papers have found a structurally different relation between trade liberalization and agglomeration. Paluzie (2001) is a good example of this. Within the framework of a two-region domestic country and a third external region, Paluzie (2001) analyzes the location process of the mobile industry following international trade liberalization. In contrast to Krugman and Elizondo (1996), Paluzie (2001) finds that trade liberalization favors regional polarization in the two-region country. Crozet and Koenig Soubeyran (2004) adopt a model that is similar in spirit. Their results show that agglomeration may occur either in the region that is located in proximity to the external region or alternatively in the interior region. Which region will contain the agglomeration depends 
on the underlying centripetal force. In the case where trade liberalization makes the external market more attractive, the border region will have the locational advantage. However, the ease of international trade may also put increased competitive pressure on firms in the border region from increased imports, which may motivate them to locate in the interior region (see Crozet and Koenig Soubeyran, 2004). Similar findings of such a positive relation between international trade liberalization and regional divergence are presented by Alonso-Villar (1999); Montfort and Nicolini (2000); and Brülhart, Crozet, and Koenig (2004).

Empirical evidence in support of the relation between international trade liberalization and location is limited. An important exception is Hanson (1996, 1997, 1998), who offers important empirical evidence for Mexico, showing the growing importance of states close to the U.S. at the expense of the initial center of manufacturing in the form of Mexico City. ${ }^{4}$ Brülhart, Crozer, and Koenig (2004) also identify the importance of border regions under trade liberalization. They perform simulations of the effect on EU regions of the entrance of the 10 transition countries and find that those regions that are relatively close to the transition countries and also relatively far from centers in the preenlargement EU are the most likely to benefit from the accession (see Brülhartt, Crozer, and Koenig, 2004).

\subsection{First- and Second-Nature Advantages}

As Head and Mayer (2004) note, there are several theories that explain firm location, each attaching importance to different location factors. A basic distinction between types of location factors is first-nature versus second-nature advantages. First-nature or "natural” advantages (Ellison and Glaeser 1997, 1999) consist of the physical geography of coasts, mountains, proximity, etc. For instance, Gallup, Sachs, and Mellinger (1999) find positive correlations between per capita income and first-nature variables such as access to coast, low level of malaria, and large hydro-carbon endowments. ${ }^{5}$

The regional distribution of resource endowments can also be seen as a first-nature advantage. Classical trade theory states that a country specializes in the industry that uses the production factor that the country has in relative abundance (Ohlin 1933). This idea can similarly be applied to regions within a country: an industry locates in a region that is abundant in resources that are used intensely in the industry. In this manner we can interpret regional resources as a source of first-nature advantage as long as we take the distribution of factors of production to be exogenous to the distribution of economic activity at a given time. ${ }^{6}$ Kim (1995) is an often-referred-to empirical study containing evidence in support of classical trade theory. For U.S. states, Kim regresses Gini coeffi-

\footnotetext{
${ }^{4}$ We discuss Hanson's findings on Mexico in more detail in Section three.

${ }^{5}$ See also Sachs (2000).

${ }^{6}$ This assumption has been challenged, as the distribution of factors of production is likely to be endogenous, especially in the long run (Overman, Redding, and Venables 2001; Brakman, Garretsen, and van Marrewijk 2001).
} 
cients for a set of two-digit industries for the period 1880-1987 on a set of control variables, including resource intensity. The estimations show a significant effect of the resource intensity variable, supporting the classical trade argument. Further evidence of the importance of the regional distribution of resources is presented by Elison and Glaeser (1999), who conclude that at least half of the level of industry concentration for U.S. industries can be explained by resource-related, first-nature advantage.

Second-nature advantage can aptly be described as "the geography of distance between economic agents” (Overman, Redding, and Venables 2001, p. 2), consisting of access to markets, access to inputs, and access to ideas. NEG represents one interpretation of this, analyzing the interactive relation between trade costs, scale economies, and the market. In this analysis, the focus exclusively lies on either access to markets (Krugman 1991) or access to inputs (Krugman and Venables 1995; Venables 1996).

The alternative interpretation of second-nature effects is that they consist of technological externalities that are caused by agglomeration. Marshall (1890) introduced the notion of agglomeration economies, linking geographical concentration of firms to placebased productivity effects in the form of externalities. Such externalities are created as the agglomeration allows for the existence of a thick labor market, specialized non-traded inputs, and knowledge spillovers (Eberts and McMillen 1999).

A firm in a given industry benefits from locating with other firms in the same industry if its productivity level increases due to externalities arising from the presence of the other firms. In this case, the externalities are labeled localization economies as the externalities remain within the industry (Eberts and McMillen 1999). In addition to localization economies, firms that locate in an agglomeration may also benefit from urbanization economies: externalities that are external to any specific industry in the agglomeration but internal to the entire agglomeration. The concept of agglomeration economies has recently been reinterpreted in a dynamic setting where regional growth is explained by the occurrence of dynamic place-based externalities (Hanson 2001). In particular, knowledge spillovers that are facilitated by geographical proximity of economic agents and the regional build up of stocks of knowledge are seen as key factors in explaining sustained differences in productivity growth between different cities or regions (Henderson 2001).

Empirical research on static agglomeration economies typically consists of the estimation of some type of production function for regional or city-industries, including size of the industry (localization economies) and of the entire agglomeration (urbanization economies) as determinants of productivity. As several surveys of this type of research have shown, there is ample evidence indicating the presence of agglomeration economies in the form of localization and/or urbanization externalities (Moomaw 1981; Gerking 1994; Eberts and McMillen 1999). An example of evidence on dynamic externalities is offered by Glaeser et al. (1992), who regress city-industry employment growth for U.S. metropolitan areas for the period 1965-1987 on a set of control variables, including base-year values for regional specialization and diversity. They find that initial 
diversity has a significant positive effect, whereas the effect from specialization is not significant. In related empirical work, Henderson, Kuncoro, and Turner (1995) show evidence in support of either localization or urbanization dynamic externalities, depending on the age of the industry. Henderson's (1997) findings are in support of the importance of dynamic localization externalities only. Although it is unclear whether regional diversity or specialization is important in creating place-based externalities, there appears to be a considerably consensus that these dynamic externalities are particularly important in explaining firm location and regional growth (Henderson 2001; Hanson 2001).

\section{EMPIRICAL SETTING: TRADE LIBERALIZATION AND LOCATION}

Starting in the period after World War II, Mexico implemented a strict development strategy of import substitution to promote domestic manufacturing industries. During this time of increasing international trade costs, economic activity came to be centered in and around Mexico City. ${ }^{7}$ Figure 1 shows the location of Mexico City in the country and the states that share a border with the U.S. This suggests that increasing trade costs stimulate agglomeration (Krugman and Elizondo 1996). ${ }^{8}$

After this period of stringent import substitution, Mexico suddenly changed its development strategy in 1985, initiating a strategy of trade liberalization and export promotion. Subsequently, Mexico continued this process by entering the General Agreement of Tariffs and Trade (GATT) in 1988. This drive towards free trade culminated in the creation of the North American Free Trade Agreement (NAFTA) between Canada, the U.S., and Mexico in 1994, representing one of the largest free trade areas in the world.

An important indication of the effect of trade strategy on industry location can be inferred from the changes in regional employment shares during this period. Following recent NEG models, we focus on the shares of the interior region (Mexico City) and the border region as the two main areas of interest. Table 1 presents regional employment shares for these areas for the period 1970-2003.

Hanson (1996, 1997) reported on the break up of the old manufacturing belt for the period until 1988, finding a strongly decreasing share in manufacturing employment for Mexico City. Table 1 show that this trend has further continued into the 1990s, stabilizing in 2003. In a 33-year period, the share of Mexico City in overall manufacturing employment has halved from 42 to 21 percent. During the same period, the border states experienced a continued growth of their share in manufacturing employment, culminating into a share of 35 percent in 2003. These changes in regional employment shares show that

\footnotetext{
${ }^{7}$ In the remainder of this paper, we define Mexico City as the Federal District and Estado de Mexico.

${ }^{8}$ Additional factors that contributed to the large growth of Mexico City were favorable regional policies (Romero Kolbeck and Urquidi 1952; Aguilar 1999) and the presence of strong push factors stimulating migration from rural to urban areas (Alba 1982).
} 


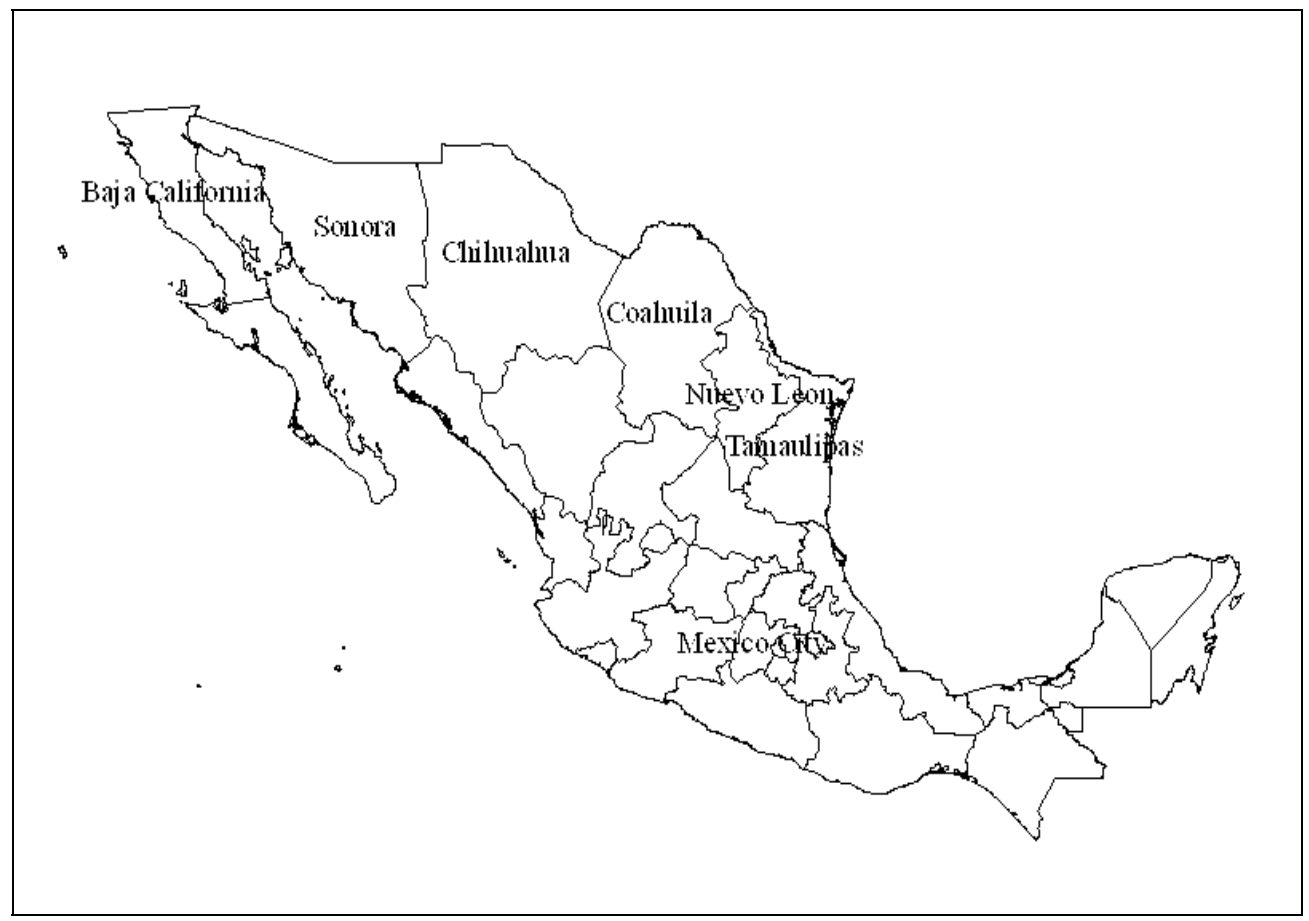

FIGURE 1. Mexico City and the Border States

trade liberalization has been accompanied by the growth of a new agglomeration of economic activity close to the border with the U.S., to the detriment of Mexico City.

It is important to note that individual trends of the nine two-digit industries show considerable variability in location behavior. Especially the industry of metal products shows a strong decrease in Mexico City and an increase in the border area. This economic activity incorporates several industries that are strong participants in the Maquiladora program (Sklair 1993). Good examples of this are activities such as car, television, and computer assembly. ${ }^{9}$ Firms operating in the Maquiladora program are heavily dependent on the U.S., both as a source of inputs and as a destination market for assembled intermediate and final products. As such, these activities are likely to have been particularly sensitive to the opening of the external market, and the changes in the regional employment shares shown in Table 1 appear to confirm this. ${ }^{10}$

\footnotetext{
${ }^{9}$ See Inegi (2004).

${ }^{10}$ Although the change in relative employment shares of the industry of basic metals also appears to suggest a relocation from Mexico City towards the border states, inspection of industry employment data reveals that this is not the case. Instead, the changes in employment shares are mainly explained by a strong decrease in the number of employees in Mexico City in the late 1990s, giving greater weight to the two stable traditional northern centers of basic metal industries in the cities of Monterrey, Nuevo Leon, and Monclova, Coahuila.
} 
TABLE 1

Regional Employment Shares: 1970-2003

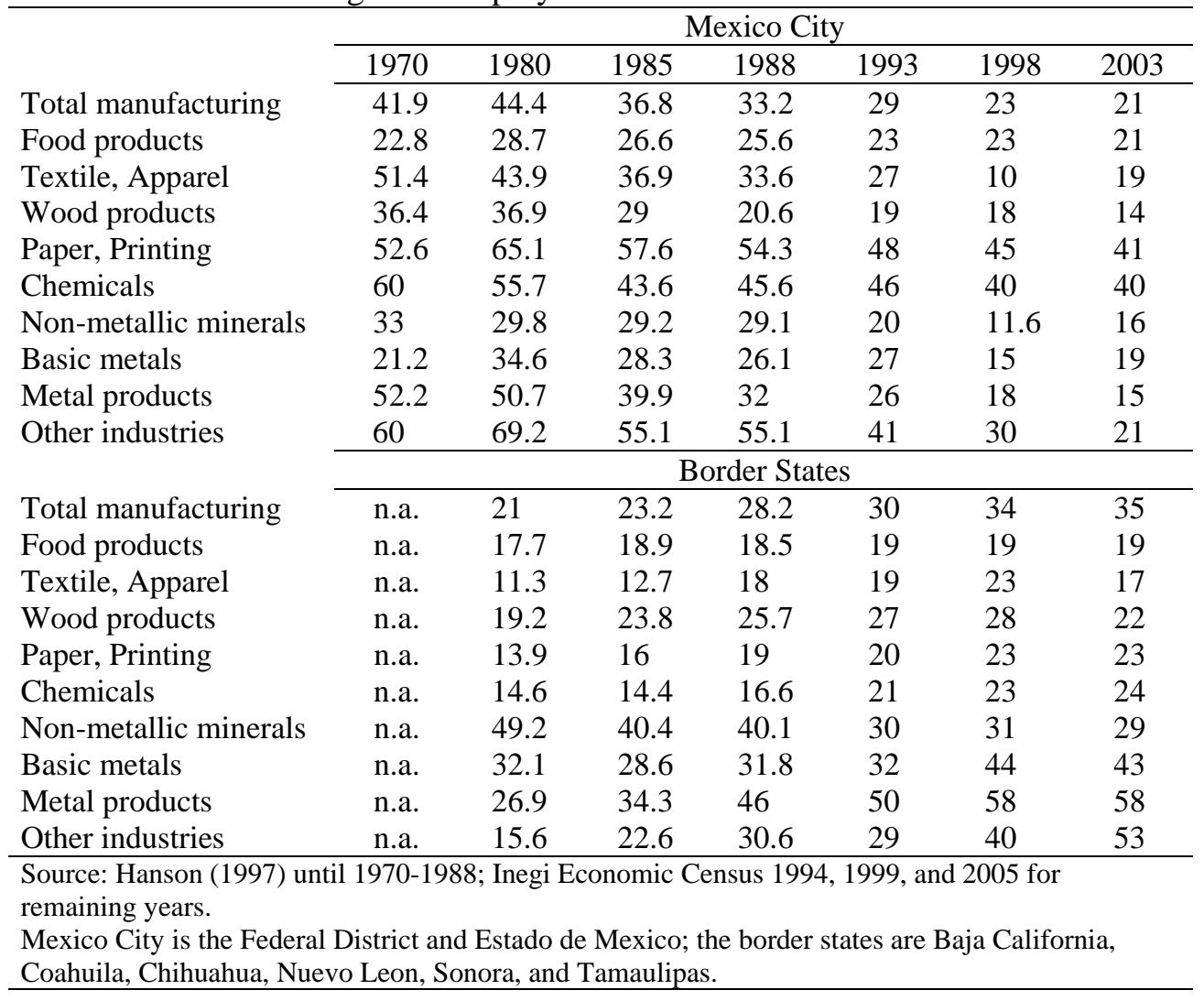

In general, the changes in regional employment shares are in line with NEG models that predict that trade liberalization stimulates regional convergence, following the growing importance of the new market in the exterior region. Hanson $(1996,1998)$ offers further empirical evidence that shows the importance of proximity to the market as a location factor as well as the change in relative importance of Mexico City and the U.S. as main markets. Hanson (1996) estimates the effect of distance to Mexico City on relative wages in the apparel industry before and after trade liberalization and finds that wages are negatively associated with distance to the capital city as a main market. This effect decreases significantly after trade liberalization in 1988. Furthermore, Hanson (1998) regresses regional employment growth on a set of control variables and finds that proximity to the U.S. has a significant positive estimated effect on regional employment growth.

Changes in the relative importance of markets should be visible in changes in relative regional wage levels. As NEG models show, agglomeration leads to spatial variation of factor rewards. Hanson (1997) applies this idea empirically and shows that a majority of 
two-digit industries in Mexican regions experienced wage increases relative to Mexico City until 1988, suggesting that the negative effect of distance to the capital as the main market decreased. In Table 2, we show the levels of regional relative wages of the border states for the period 1980-2003.

Compared to the period of import substitution, the period of trade liberalization that started in the late 1980s and further increased from the mid-1990s onwards has led to an improvement of nominal average wages in the border states relative to Mexico City except for the chemical industry. This suggests that the effect of Mexico City as the main market has decreased, weakening the spatial wage gradient around the traditional manufacturing belt. Furthermore, this compression of nominal wages during the period of trade liberalization also seems to show the increasing magnitude of the positive effect of proximity to the U.S. market. In fact, as six out of nine regional industries in the border area show relative nominal wages larger than 1 in 2003, it appears that proximity to the U.S. market has started to outweigh proximity to the old agglomeration, Mexico City.

Summarizing, we have identified two main features of the location pattern of Mexican manufacturing industries before and after trade liberalization. First, following initial developments in the 1980s, the break up of the traditional manufacturing belt in Mexico City continued steadily in the 1990s and seems to have stabilized in the period after 1998. In roughly 30 years' time, the share of Mexico City in total manufacturing has halved. In the same time period, the border states continued to see their share in manufacturing grow considerably and consistently. These combined developments are in line with NEG models that predict de-agglomeration following trade liberalization in favor of the region with favorable access to the external region. At the same time, it is important to recognize that there is variation among industries, suggesting that the relation between trade costs and industry location is likely to differ between individual industries.

TABLE 2

Relative Wages in Border States: 1980-1998

\begin{tabular}{llllll}
\hline \multicolumn{1}{c}{ Industry } & 1980 & 1988 & 1993 & 1998 & 2003 \\
\hline Food products & 0.776 & 0.882 & 0.899 & 0.827 & 0.904 \\
Textile, Apparel & 0.857 & 0.917 & 0.771 & 0.995 & 0.981 \\
Wood products & 0.729 & 0.905 & 0.901 & 1.21 & 1.42 \\
Paper, Printing & 0.864 & 0.705 & 0.924 & 0.718 & 1.05 \\
Chemicals & 0.825 & 0.868 & 0.747 & 0.711 & 0.78 \\
Non-metallic minerals & 0.624 & 0.782 & 0.933 & 0.839 & 1.04 \\
Basic metals & 1.24 & 0.785 & 2.21 & 1.694 & 2.03 \\
Metal products & 0.743 & 0.812 & 0.686 & 0.813 & 1.11 \\
Other industries & 0.735 & 0.760 & 0.744 & 0.908 & 1.13 \\
\hline $\begin{array}{l}\text { Source: Hanson (1997) } \\
\text { remaining years. }\end{array}$ & $1980-1988 ;$ Inegi Economic Census 1994, 1999 , and 2005 for \\
Relative wages are nominal average wages in two-digit industry in border states / nominal \\
average wages in two-digit industry in Mexico City.
\end{tabular}


Second, changes in regional relative wage levels of the border states also suggest that distance to the manufacturing center Mexico City has become less important than was previously the case. Compared to the period of import substitution, the majority of relative nominal regional industry wages in the border area have improved considerably. This both suggests that the negative wage effect from distance to Mexico City has decreased and also that there is a positive wage effect from proximity to the U.S. market. In fact, after a period of compressing wage differentials, the figures for 2003 show an increase in the wage differential of several industries, but this time at the expense of industries located in proximity to Mexico City.

\section{SPECIFICATION OF EMPIRICAL MODEL}

In our empirical analysis, we look at the relation between trade liberalization and industry location. In particular, we concentrate on three issues. First, we want to statistically identify the effect of distance to the market on industry location. Importantly, as our empirical analysis starts from the time period of import substitution, we also include the effect of externalities in our empirical model, as this factor has been modeled as a factor stimulating agglomeration under trade restriction (Krugman and Elizondo 1996). Second, we want to assess whether the effects of the market and externalities change with increasing trade liberalization. We use census data from 1985, 1988, 1993, and 1998. ${ }^{11}$ During this time period, the Mexican market was subject to a process of increasing liberalization. We distinguish between three periods: import substitution $(1985,1988)$, initial trade liberalization (1993), and NAFTA integration (1998). By comparing estimated coefficients of right-hand side variables between these periods, we are able to assess whether their effects have changed as a result of increasing trade liberalization. Third, we want to explore the extent of industry heterogeneity in the relation between trade and location. NEG models do not allow for the presence of such industry heterogeneity. By estimating the empirical model for individual industries, we can obtain an indication of the extent to which the relationship applies to different types of industries.

We estimate the effect of the second-nature advantages on industry location with the following empirical model.

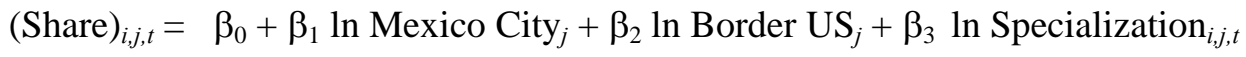

$$
\begin{aligned}
& +\beta_{4} \ln \text { Diversity }_{i, j, t}+\varphi i+\chi t+\varepsilon
\end{aligned}
$$

where $i, j, t$, = industry, state, time and $\varphi i, \chi t=$ industry fixed effects, year fixed effects.

\footnotetext{
${ }^{11}$ We have not included 2003 into our main empirical analysis as we have not yet been able to convert the 2003 data at the disaggregate aggregate level into a format that is comparable with previous census years. This requires a conversion of the 2001 SCIAN classification system into the 1997 version, after which the 1997 SCIAN version needs to be converted into the 1993 CMAP classification system. We do not think that the omission of 2003 affects our present empirical estimations, as Table 1 shows a considerable stabilization of the industry location patterns after 1998 in terms of the relative importance of Mexico City and the border states.
} 
Our dependent variable, Share, is the share of a state industry in total industry employment in the country. We capture the market effect in the model by the distance of the regional industry shares from Mexico City and the border with the U.S. ${ }^{12}$ All else equal, we expect regional industry shares to decrease with growing distance to either of these two market areas if proximity to the market is a significant location factor.

As for the effect of externalities, we control for both the effect from regional specialization (localization) and from diversity (urbanization), in line with the fact that externalities can arise within and/or between industries. We calculate regional specialization as follows.

$$
\text { Specialization }_{\mathrm{i}, \mathrm{j}}=\frac{(E i j / E j)}{\left(\sum_{1}^{j} E i j / \sum_{1}^{j} \sum_{1}^{i} E i j\right)} \text {, where } E \text { is number of employees. }
$$

This specification gives us a location quotient for an industry in a state that increases with the size of the industry in state manufacturing employment, relative to the national industry's share in national manufacturing employment. We take a significant positive estimated coefficient as evidence of the existence of positive localization economies.

We follow Combes (2000) in calculating diversity as:

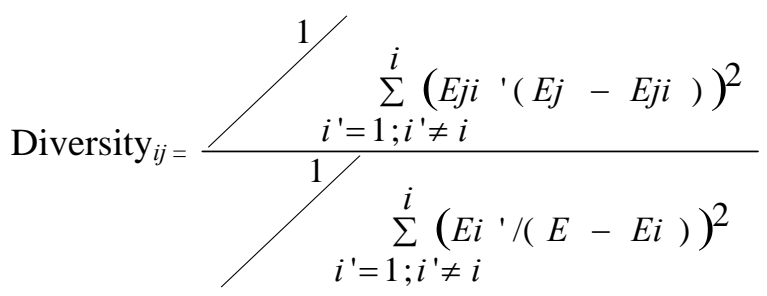

This specification is a relative Herfindahl-Hirschman index that increases with state manufacturing diversity for a given industry. We take a significant positive estimated coefficient of this variable as evidence of the existence of urbanization economies. ${ }^{13}$

\footnotetext{
${ }^{12}$ Distance between states is measured as distance in kilometers between state capital cities taken from http://www.trace-sc.com/maps_en.htm

${ }^{13}$ We have chosen these specifications of specialization and diversity as they are not necessarily opposites of each other; i.e., for a given industry, diversity is not necessarily negatively linked to own specialization. The motivation for this is that both specialization and diversity can have similar effects on regional industry employment shares.
} 
As discussed previously, an important distinction has recently been made between static externalities and dynamic externalities (Hanson 2001). Besides the time dimension of when externalities materialize (Quigley 1998), static and dynamic externalities may be related to different types of effects. Static externalities are responsible for a one-off decrease in costs or increase in productivity, whereas dynamic externalities represent underlying processes that cause continuous decreases in costs or increases in productivity (McDonald 1997; Hanson 2001). Given these distinctions between static and dynamic externalities, we experiment with current and lagged values of the specialization and diversity variables in our empirical estimations.

Finally, we need to discuss the error structure of our empirical model. Our dataset contains three possible sources of heterogeneity in the form of industry effects, time effects, and state effects. However, the inclusion of the distance variables prevents us from including state fixed effects. We follow the idea introduced by Hanson (1997), who faced a similar problem in his analysis of regional wage structures. We first estimate the empirical model with fixed industry and time effects and the two distance variables. The distance variables pick up transport costs and any other state effects that are related to distance. We then re-estimate the empirical model substituting state fixed effects for the distance variables. Finally, to determine the relative importance of distance among the set of state characteristics, we regress the estimated coefficients of the state dummies on the distance variables.

\section{EMPIRICAL FINDINGS}

\subsection{The General Effect of Distance: 1985-1998}

Our first question is whether distance to the market is an important location factor. To answer this question, we estimate several specifications of our reduced form model. The main findings are presented in Table 3.

Column (1) shows the results of regressing regional industry shares on distance to the two main markets. The estimated coefficients of both distance variables carry negative signs and are significant at the 1 percent level, confirming the negative effect of distance to the main markets. Columns (2) to (4) add the regional specialization and diversity variables to the model and test for the significance of year and industry fixed effects. An important difference with the initial findings is that the estimated negatively signed coefficients of the distance variables decrease, suggesting that the initial estimations were biased due to the omission of regional specialization and diversity. As for the estimated effects of the externality variables, they show positively signed significant coefficients in the various specifications, confirming their positive effect on industry location. 
TABLE 3

Distance, Externalities and Agglomeration: 1985-1998

\begin{tabular}{ccccccc}
\hline Rhs variables & \multicolumn{1}{c}{$(1)$} & \multicolumn{1}{c}{$(2)$} & \multicolumn{1}{c}{$(3)$} & \multicolumn{1}{c}{$(4)$} & $(5)$ \\
\hline Constant & 0.0001 & 0.0001 & 0.0001 & 0.07 & -0.22 & -0.52 \\
& $(0.009)$ & $(0.008)$ & $(0.008)$ & $(0.06)$ & $(0.07)^{* * *}$ & $(0.09)^{* * *}$ \\
Distance to & -0.42 & -0.37 & -0.35 & -0.36 & -0.29 & -- \\
Mexico City & $(0.01)^{* * *}$ & $(0.009)^{* * *}$ & $(0.009)^{* * *}$ & $(0.009)^{* * *}$ & $(0.01)^{* * *}$ & \\
Distance to Border & -0.06 & -0.05 & -0.04 & -0.04 & -0.03 & - \\
& $(0.01)^{* * *}$ & $(0.008)^{* * *}$ & $(0.008)^{* * *}$ & $(0.008)^{* * *}$ & $(0.009)^{* * *}$ & \\
Specialization & -- & 0.42 & 0.42 & 0.44 & 0.35 & 0.37 \\
& & $(0.008)^{* * *}$ & $(0.008)^{* * *}$ & $(0.008)^{* * *}$ & $(0.009)^{* * *}$ & $(0.008)^{* * *}$ \\
Diversity & -- & 0.22 & 0.25 & 0.25 & 0.29 & 0.11 \\
& & $(0.009)^{* * *}$ & $(0.009)^{* * *}$ & $(0.009)^{* * *}$ & $(0.01)^{* * *}$ & $(0.02)^{* * *}$ \\
Year fixed effect & No & No & Yes & Yes & Yes & Yes \\
Industry fixed effect & No & No & No & No & Yes & Yes \\
State fixed effects & No & No & No & No & No & Yes \\
Heteroscedasticity & Yes & Yes & Yes & Yes & Yes & Yes \\
Adj R & 0.18 & 0.41 & 0.42 & 0.43 & 0.34 & 0.48 \\
F & 319 & 773 & 773 & 103.76 & 60.51 & 71.2 \\
N & 8640 & 8640 & 8640 & 8640 & 6912 & 6912 \\
\hline
\end{tabular}

Estimations are heteroscedasticity robust, using Stata version 9. Robust Standard errors between brackets. Columns 3, 4, $5=$ specialization $_{\mathrm{t}}$ and diversity ; column 5 and $6=$ specialization $_{\mathrm{t}-1}$ and diversity $\mathrm{t}_{\mathrm{t}-1}$

***, $* *$ and * indicate significance at 1,5 and $10 \%$. All variables are standardized.

As discussed in the previous section, an important issue regarding the externality variables is that their effect may take time to materialize. Column (5) contains the result from estimating the empirical model with lagged externality variables. The estimated values of the coefficients are not considerably different. However, we will use the lagged values for specialization and diversity in the remainder of this paper. One reason for this is that lagged externality variables are more appropriate if our interest lies in regional employment growth (see Glaeser, Hedi, and Scheinkman 1992; Henderson, Kuncoro, and Turner 1995). Furthermore, the use of lagged values of specialization and diversity lowers the possibility that the estimated effects are influenced by simultaneity bias. ${ }^{14}$

Finally, column (6) contains the result of the regression where state fixed effects are substituted for the distance variables. The increase in adjusted $\mathrm{R}^{2}$ indicates that the distance variables are part of, but do not capture the entire effect of, the state fixed effects. Having said so, we can use the results from column (6) to obtain a further indication of the importance of distance. We regress the estimated coefficients of the state dummies on the distance variables and a constant. This regression produces an adjusted $\mathrm{R}^{2}$ of 0.40 , which shows that the distance variables represent an important component of

\footnotetext{
${ }^{14}$ See Brakman, Garretsen, and van Marrewijk (2001) and Combes and Overman (2004).
} 
the overall state fixed effects. This supports the finding that distance to the market is an important location factor.

\subsection{The Effect of the Market Under Trade Liberalization}

The empirical findings in the previous section confirm the expected negative relation between proximity to the market and location of industries. In order to get an indication of the relation between industry location and trade liberalization, we take advantage of the rich nature of our dataset. Our dataset can be divided into three different time periods representing import substitution $(1985,1988)$, initial trade liberalization (1993), and NAFTA integration (1998). We estimate the empirical model as developed in the previous section for each of the separate time periods. The results of this set of regressions are shown in Table 4.

The results contain two important sets of findings. First, both types of dynamic externalities affect location in all periods. Estimated coefficients differ somewhat between periods, but these differences are not significant. Therefore, the findings show that externalities from regional specialization and diversity are important location factors, irrespective of the level of trade liberalization. Second, the change in the estimated coefficients of the distance variables for the different time periods show that trade liberalization has made the border region more attractive at the expense of the old manufacturing belt Mexico City

\section{TABLE 4}

Distance, Externalities and Trade Liberalization

\begin{tabular}{|c|c|c|c|c|}
\hline Rhs variables & 1985 & 1988 & 1993 & 1998 \\
\hline Constant & $\begin{array}{c}0.07 \\
(0.14)\end{array}$ & $\begin{array}{c}0.11 \\
(0.13)\end{array}$ & $\begin{array}{c}0.12 \\
(0.14)\end{array}$ & $\begin{array}{c}0.07 \\
(0.15)\end{array}$ \\
\hline Distance to Mexico City & $\begin{array}{l}-0.32 \\
(0.02)^{* * *}\end{array}$ & $\begin{array}{l}-0.33 \\
(0.02)^{* * *}\end{array}$ & $\begin{array}{l}-0.27 \\
(0.02)^{* * *}\end{array}$ & $\begin{array}{l}-0.23 \\
(0.02)^{* * *}\end{array}$ \\
\hline Distance to Border & $\begin{array}{c}0.01 \\
(0.01)\end{array}$ & $\begin{array}{c}0.01 \\
(0.02)\end{array}$ & $\begin{array}{l}-0.04 \\
(0.02)^{* *}\end{array}$ & $\begin{array}{l}-0.12 \\
(0.02)^{* * *}\end{array}$ \\
\hline Specialization & $\begin{array}{l}0.29 \\
(0.02)^{* * *}\end{array}$ & $\begin{array}{l}0.38 \\
(0.02)^{* * *}\end{array}$ & $\begin{array}{l}0.45 \\
(0.02)^{* * *}\end{array}$ & $\begin{array}{l}0.34 \\
(0.02)^{* * *}\end{array}$ \\
\hline Diversity & $\begin{array}{l}0.32 \\
(0.02)^{* * *}\end{array}$ & $\begin{array}{l}0.24 \\
(0.02)^{* * *}\end{array}$ & ${ }^{0.28}(0.02)^{* * *}$ & ${ }^{0.28}(0.02)^{* * *}$ \\
\hline Industry fixed effect & Yes & Yes & Yes & Yes \\
\hline Heteroscedasticity & Yes & Yes & Yes & Yes \\
\hline Adj $\mathrm{R}^{2}$ & 0.35 & 0.36 & 0.39 & 0.26 \\
\hline $\mathrm{F}$ & 17.52 & 17.83 & 20.26 & 11.43 \\
\hline $\mathrm{N}$ & 1728 & 1728 & 1728 & 1728 \\
\hline
\end{tabular}


In 1985 and 1988, the years representing import substitution, distance to the capital has a significant negative effect. In contrast, distance to the U.S. has no significant effect. The initiation of trade liberalization after 1988 then starts to have an effect on location. The findings for 1993 show that the estimated coefficient of distance to the capital decreases, whereas the effect of distance to the U.S. becomes significant. Finally, the effect of the further increase of trade liberalization following the creation of the NAFTA in 1994 can be seen in the findings for 1998. The estimated effect of distance to the capital has decreased further, and the effect of distance to the U.S. has significantly increased in magnitude.

These changes of the coefficients are in line with recent NEG models that predict increased regional convergence following trade liberalization. The opening up of the market has lowered the importance of being close to the old manufacturing center, captured by the decrease in the estimated coefficient of Mexico City. At the same time, the external market has become relevant in location processes, which is captured in the significance of the estimated coefficient of the U.S. variable in 1993 and its further increase in 1998. The combined effect of these changes is that economic activity has deagglomerated in favor of the border states.

\subsection{Distance and Individual Industries}

In order to explore the level of industry heterogeneity concerning the importance of distance to main markets, we performed regressions for the nine industry groupings as listed in Table 1. The results are shown in Table 5 below.

Again, the generality of the positive effect of both regional specialization and diversity is confirmed. Both variables carry significant estimated coefficients in the estimations of all nine sub-sectors, showing that externalities from specialization and diversity are significant location factors for all types of industries during trade liberalization. One difference between the two externality variables is that whereas diversity carries a stable coefficient for all industries, the estimation effect of specialization ranges considerably.

The estimated negative effect of distance to Mexico City also applies to all industry groupings. This shows the strength of the attractive power of this agglomeration that was created during import substitution when it represented the main market for all industries. This is not the case for the U.S. market. Three industries appear to be particularly influenced by distance to the new market. The industries of wood products, metal products and other industries show negatively signed significant coefficients for the variable of distance to the U.S. 
TABLE 5

Regressions for Two-Digit Industries; 1988-1998

\begin{tabular}{|c|c|c|c|c|c|c|c|c|c|}
\hline RHS variables & Food & $\begin{array}{l}\text { Textile, } \\
\text { apparel }\end{array}$ & Wood & Paper & Chemical & $\begin{array}{c}\text { Non-metallic } \\
\text { minerals }\end{array}$ & $\begin{array}{l}\text { Basic } \\
\text { metals }\end{array}$ & $\begin{array}{c}\text { Metal } \\
\text { products }\end{array}$ & Other \\
\hline Constant & $\begin{array}{l}-0.14 \\
(0.03)^{* * *}\end{array}$ & $\begin{array}{c}0.07 \\
(0.05)\end{array}$ & $\begin{array}{l}-0.12 \\
(0.06)^{* * *}\end{array}$ & $\begin{array}{l}-0.05 \\
(0.08)\end{array}$ & $\begin{array}{l}0.11 \\
(0.06)^{* *}\end{array}$ & $\begin{array}{l}-0.14 \\
(0.06)\end{array}$ & $\begin{array}{l}-0.03 \\
(0.09)\end{array}$ & $\begin{array}{l}-0.18 \\
(0.03)^{* * *}\end{array}$ & $\begin{array}{l}-0.06 \\
(0.10)\end{array}$ \\
\hline Distance to Mexico City & $\begin{array}{l}-0.22 \\
(0.02)^{* * *}\end{array}$ & $\begin{array}{l}-0.27 \\
(0.03)^{* * *}\end{array}$ & $\begin{array}{l}-0.22 \\
(0.03)^{* * *}\end{array}$ & $\begin{array}{l}-0.75 \\
(0.05)^{* * *}\end{array}$ & $\begin{array}{l}-0.46 \\
(0.03)^{* * *}\end{array}$ & $\begin{array}{l}-0.10 \\
(0.03)^{* * *}\end{array}$ & $\begin{array}{l}-0.13 \\
(0.05)^{* * *}\end{array}$ & $\begin{array}{l}-0.27 \\
(0.02)^{* * *}\end{array}$ & $\begin{array}{l}-0.76 \\
(0.05)^{* * *}\end{array}$ \\
\hline Distance to border & $\begin{array}{c}0.02 \\
(0.02)\end{array}$ & $\begin{array}{r}0.007 \\
(0.25)\end{array}$ & $\begin{array}{l}-0.10 \\
(0.03)^{* * *}\end{array}$ & $\begin{array}{l}-0.07 \\
(0.04)^{*}\end{array}$ & $\begin{array}{c}0.01 \\
(0.41)\end{array}$ & $\begin{array}{c}0.01 \\
(0.03)\end{array}$ & $\begin{array}{c}0.05 \\
(0.05)\end{array}$ & $\begin{array}{l}-0.08 \\
(0.02)^{* * *}\end{array}$ & $\begin{array}{l}-0.23 \\
(0.05)^{* *} *\end{array}$ \\
\hline Specialization & $\begin{array}{l}0.15 \\
(0.01)^{* * *}\end{array}$ & $\begin{array}{l}0.65 \\
(0.03)^{* * *}\end{array}$ & $\begin{array}{l}0.42 \\
(0.03)^{* * *}\end{array}$ & $\begin{array}{l}0.59 \\
(0.16)^{* * *}\end{array}$ & $\begin{array}{l}0.53 \\
(0.03)^{* * *}\end{array}$ & $\begin{array}{l}0.73 \\
(0.06)^{* * *}\end{array}$ & $\begin{array}{l}0.88 \\
(0.09)^{* * *}\end{array}$ & $\begin{array}{l}0.89 \\
(0.04)^{* * *}\end{array}$ & $\begin{array}{l}0.38 \\
(0.16)^{* * *}\end{array}$ \\
\hline Diversity & $\begin{array}{l}0.29 \\
(0.02)^{* * *}\end{array}$ & $\begin{array}{l}0.23 \\
(0.03)^{* * *}\end{array}$ & $\begin{array}{l}0.17 \\
(0.03)^{* * *}\end{array}$ & $\begin{array}{l}0.25 \\
(0.05)^{* * *}\end{array}$ & $\begin{array}{l}0.29 \\
(0.04)^{* * *}\end{array}$ & $\begin{array}{l}0.34 \\
(0.03)^{* * *}\end{array}$ & $\begin{array}{c}0.37 \\
(0.05)\end{array}$ & $\begin{array}{l}0.25 \\
(0.02)^{* * *}\end{array}$ & $\begin{array}{l}0.20 \\
(0.05)^{* * *}\end{array}$ \\
\hline Year fixed effect & Yes & Yes & Yes & Yes & Yes & Yes & Yes & Yes & Yes \\
\hline Heteroscedasticity & Yes & Yes & Yes & Yes & Yes & Yes & Yes & Yes & Yes \\
\hline Adj $R^{2}$ & 0.33 & 0.47 & 0.44 & 0.68 & 0.37 & 0.38 & 0.50 & 0.45 & 0.73 \\
\hline $\mathrm{F}$ & 117.53 & 112.93 & 44.77 & 79.29 & 98.61 & 45.72 & 37.09 & 197.10 & 50.39 \\
\hline $\mathrm{N}$ & 1664 & 896 & 384 & 256 & 1152 & 512 & 256 & 1664 & 128 \\
\hline \multicolumn{10}{|c|}{$\begin{array}{l}\text { Industries have different number of observations due to differences in the level of subdivision beyond the two-digit level. The one extreme } \\
\text { is the industry of basic metals with only two four-digit industries. With } 13 \text {, the industry of food has highest most number of four-digit } \\
\text { industries. In all estimations, specialization and diversity are t- } 1 \text {. Estimations are heteroskedasticity robust, using Stata version } 9 \text {; Robust } \\
\text { Standard errors between brackets. All variables are standardized. } \\
* * *, * * \text { and } * \text { indicate significance at } 1,5 \text { and } 10 \% \text {. }\end{array}$} \\
\hline
\end{tabular}


The estimations for separate industry groupings show that distance to the new market is not a relevant location factor for all industries. However, the use of these broad industry groupings is likely to hide a substantial amount of heterogeneity at the individual industry level. In order to obtain a more detailed impression of the effects of the secondnature advantages, we ran separate estimations for all the 54 regional industries for the period 1988-1998. Based on the significance of the estimated coefficients of the externality and distance variables, we classified the 54 individual industries into three groups of industries: industries where distance to markets is insignificant, industries where only distance to Mexico City is important, and industries where distance to the U.S. is also important. The sets of industries are shown in Table 6 .

Industries listed under the heading "Specialization/Diversity" are not significantly affected in their location by either distance to Mexico City or the U.S. It appears that this type of industry particularly consists of natural resource-intensive industries. These industries locate at sites where resources are obtained, irrespective of location of destination markets. Typical examples of industries showing this type of location behavior include the petrochemical industry, basic metal industry, the tobacco industry, and industries of food products.

\section{TABLE 6}

Individual Industries and Second-Nature Advantages

\section{Specialization / Diversity}

Meat products; other food and kindred products (vegetable oils, sugar); animal food processing; textile mill products; tobacco; apparel; lumber industry; petrochemical industry; chemicals for agricultural industries; oil refinery; ceramics; clay products for construction industries; ferrous and non-ferrous basic metals; metal services, ordnance and fabricated products; plumbing fixtures and metal structures

\section{Distance to Mexico City}

Dairy products; grain mill products; bakery products; other food and kindred products; beverages; apparel; footgear; artificial fibers \& synthetics; medicines; soaps and detergents; products derived from coke and other mineral carbons; rubber products; plastic goods; glass products; stone, cement, clay, concrete; metal cans, forgings and stampings; farm and garden machinery; engines and turbines; electronic components and accessories; household appliances; motors

\section{Distance to U.S.}

Preserved fruits and vegetables; leather and leather products; lumber and wood products; furniture and fixtures; pulp, paper and carton; computer and office equipment; audio, video and communications equipment; transportation equipment; measuring, scientific and optical instruments; other industries

Descriptions translated from Inegi (1994). 
The second group of industries consists of those for which distance to Mexico City is a significant factor but distance to the U.S. is not. The NEG explanation for the location of this type of industries is that they concentrated production close to Mexico City under import substitution, as this agglomeration constitutes their main market. The insignificant coefficient of the U.S. distance variable for these industries suggests that under trade liberalization, Mexico City has remained the dominant market.

Finally, the last group of industry consists of those for which distance to the U.S. also has a significant effect. This set of industries appears to consist of two types. The first type consists of processed fruits and vegetables and furniture and fixtures and wood products. These industries have important shares in Mexico's exports. ${ }^{15}$ An explanation for the classification of the industries in this group may be that firms in these industries concentrate food processing and construction/assembling of furniture close to the U.S. border, after which products are then exported. ${ }^{16}$

The second type of industry in this group concerns those that are typical for the Maquiladora program. Computer and office equipment, video equipment, transportation, and measuring equipment are all prime examples of industries for which international trade has been made particularly easy after 1988, facilitating tax free re-exporting of imported components. These industries produce almost exclusively for the American market, and it is therefore not surprising to see them classified in this group. In the top 50 of most exported products to the U.S., products produced by these industries are all listed in the top $10 .{ }^{17}$ Of course, this does not mean that the Mexican market may not be important to these industries. In fact, all industries that we listed in the third category also show significant estimated negative effects from distance to Mexico City. However, the large importance of international trade is reflected in the estimated significant negative effect of distance to the U.S. border.

\section{SUMMARY AND CONCLUSIONS}

Recent NEG models incorporate an intra-country regional dimension to the analysis of the relation between trade liberalization and industry location. The results show that there is ambiguity about the nature of this relationship. Whereas some models show that trade liberalization stimulates intra-country agglomeration, other models find that lower international trade costs foster processes of intra-country dispersion of economic activity. The deciding factor in whether agglomeration or de-agglomeration occurs appears to be whether the internal or the external market becomes the dominant one.

\footnotetext{
${ }^{15}$ In 1999, products of the industries of processed fruits and vegetables and furniture classified among the top 20 of export goods according to trade statistics from the U.S.-Mexico Chamber of Commerce (http://www.usmcoc.org/eco2.html)

${ }^{16}$ Ibid.

${ }^{17}$ Ibid.
} 
In this paper, we present new empirical evidence on the location of manufacturing industries in Mexico, a country that resembles theoretical cases analyzed by recent NEG models. During the time span of our analysis, the Mexican government suddenly and radically changed its development strategy from import substitution to export promotion, thus creating a natural experiment in which we can study the relation between trade costs and industry location processes.

Changes in regional industry employment shares and regional nominal industry wages during the period 1980-2003 support the notion that trade liberalization has fostered a process of regional convergence. At the expense of the old agglomeration of economic activity Mexico City, the border states have experienced consistently growing industry employment shares, suggesting that proximity to the U.S. market has become an important location factor following trade liberalization. Changes in relative industry wages suggest a change in the relative importance of Mexico City and the U.S. as main markets. The period of trade liberalization experienced a continuous process of compression of relative nominal wages in favor of the border states, showing the change in relative importance in favor of the new destination market.

The estimations of our reduced form model offer statistical evidence on the role of second-nature advantages in firm location. First, it is important to note that externalities arising from regional specialization and from regional diversity both show a robust positive association with regional industry shares. The findings suggest that, irrespective of the time period and level of industry aggregation, regional industry specialization and regional manufacturing diversity stimulate industry agglomeration.

Second, the statistical estimations offer a variety of evidence that shows the importance of markets as location factor as well as the change in the relative importance of the interior and the exterior markets. The pooled estimations show significant negative associations between regional industry share and distance to both Mexico City and the U.S., showing the general negative effect of distance to the market on industry location. Next, regressions for the period of trade liberalization show a decrease in the estimated effect of Mexico City and an increase in the effect of the U.S. This finding offers support for NEG models that find that trade liberalization leads to regional convergence caused by the attractive power of the market in the exterior region.

Having said so, the statistical estimates also show that the old market continues to have a significant effect on location. Furthermore, estimations for individual industries reveal a considerable extent of industry heterogeneity. Regressions at the two-digit industry classification show that the U.S. market is only significantly associated with regional industry shares of selected industries. In extension of this, using regressions at the four-digit level, we can distinguish three types of industry, for two of which location to the market is significant.

One group of industries is influenced in location behavior only by the old manufacturing center Mexico City, whereas the second group is influenced by both the 
old and the new market. Recent NEG models show that trade liberalization may lead to regional divergence, when firms locate in the interior region to be protected from competition from the new exterior region. In contrast, regional convergence occurs when the exterior region becomes more attractive for firms at the expense of the old interior region as main market. Our findings show that both processes are at work in Mexican industries. Therefore, the general statistics that show an increase of the border states at the expense of the old manufacturing center Mexico City should be interpreted with the necessary caution. Our analysis at the more disaggregate level shows that for one type of industry, the U.S. market is indeed causing a relocation of industries to the border states. However, for the other type of industry, Mexico City maintains its role as the dominant market.

\section{REFERENCES}

Aguilar, A., 1999. "Mexico City Growth and Regional Dispersal: The Expansion of Largest Cities and New Spatial Forms,” Habitat International 23(3), 391-412.

Alba, F., 1982. The Population of Mexico: Trends, Issues and Policies. Transaction Books: New Brunswick, NJ.

Alonso-Villar, O., 1999. "Spatial Distribution of Production and International Trade: A Note," Regional Science and Urban Economics, 29, 371-380.

Amitri, M., 1997. "Specialization Patterns in Europe," Centre for Economic Performance, Discussion Paper no. 363, London School of Economics. , 1998. "New Trade Theories and Industrial Location in the EU: A Survey of Evidence," Oxford Review of Economic Policy 14(2), 45-53.

Behrens, K., C. Gaigné, G.I.P. Ottaviano, and J-F. Thisse, 2004. "Inter-Regional and International Trade: Seventy Years after Ohlin,” C.E.P.R. Discussion Paper No. 4065, Centre for Economic Policy Research, U.K.

Brakman, S., H. Garretsen, and C. van Marrewijk, 2001. An Introduction to Geographical Economics. Cambridge University Press: Cambridge.

Brülhart, M., M. Crozet, and P. Koenig, 2004. "Enlargement and the EU Periphery: The Impact of Changing Market Potential," The World Economy 27(6), 853-875.

Brülhart, M. and F. Trionfetti, 1998. "Industrial Specialization and Public Procurement: Theory and Empirical Evidence," Centre for Economic Performance working paper, no. 974, London School of Economics.

Combes, P.P., 2000. "Economic Structure and Local Growth: France, 1984-1993,” Journal of Urban Economics 47, 329-355.

Combes, P.P. and H. Overman, 2004. "The Spatial Distribution of Economic Activities in North America," chapter 64 in V. Henderson and J.F. Thisse (eds), Handbook of Urban and Regional Economics, Vol. 4, Elsevier, North Holland.

Coughlin, C.C., J.V. Terza, and V. Arromdee, 1991. "State Characteristics and the Location of Foreign Direct Investment Within the United States," The Review of Economics and Statistics 73(4), 675-683.

Crozet, M. and P. Koenig Soubeyran, 2004. "EU Enlargement and the Internal Geography of Countries,” Journal of Comparative Economics 32, 265-279. 
Crozet, M., T. Mayer, and J-L Mucchieli, 2004. "How Do Firms Agglomerate? A Study of FDI in France," Regional Science and Urban Economics 34(1), 27-54.

Elison, G. and E. Glaeser, 1997. "Geographic Concentration in U.S. Manufacturing Industries: A Dartboard Approach,” The Journal of Political Economy 105, 889-927. 1999. "The Geographic Concentration of Industry: Does Natural Advantage Explain Agglomeration?” The American Economic Review 89, 311-316.

Eberts, R.W. and D. McMillen, 1999. "Agglomeration Economies and Public Infrastructure,” in P. Cheshire and E.S. Mills (eds), Handbook of Urban and Regional Economics, Vol. 3, North Holland.

Fujita, M., P. Krugman, and A.J. Venables, 1999. The Spatial Economy. The MIT Press: Cambridge, MA.

Fujita, M., T. Mori, J. Henderson, and Y. Kanemoto, 2004. "Spatial Distribution of Economic Activities in Japan and China," Chapter 65 in V. Henderson and J.F. Thisse (eds), Handbook of Urban and Regional Economics, Vol. 4, Elsevier, North Holland.

Gallup, J.L., J. Sachs, and A.D. Mellinger, 1999. "Geography and Economic Development," in B. Pleskovic and J.E. Stiglitz (eds.), Annual World Bank Conference on Development Economics 1998, World Bank, Washington, D.C.

Gerking, S., 1994. "Measuring Productivity Growth in U.S. Regions: A Survey," International Regional Science Review 16, 155-186.

Glaeser, E.L., D.K. Hedi, J.A. Scheinkman, and A. Schleifer, 1992. "Growth in Cities," The Journal of Political Economy 100(6), 1126-1152.

Guimarães, P., O. Figueiredo, and D. Woodward, 2000. "Agglomeration and the Location of Foreign Direct Investment in Portugal," Journal of Urban Economic 47(1), 115-135.

Hanson, G., 1996. 'Localization economies, vertical integration and trade', American Economic Review 86, 1266-1278

, 1997. "Increasing Returns, Trade, and the Regional Structure of Wages," The Economic Journal 107, 113-133.

, 1998. "Regional Adjustment to Trade Liberalization," Regional Science and Urban Economics 28, 419-444.

, 2001. "Scale Economies and the Geographic Concentration of Industry," Journal of Economic Geography 1, 255-276.

, 2004. "Market Potential, Increasing Returns and Geographic Concentration," Journal of International Economics 67, 1-24.

Head, K. and T. Mayer, 2004. "The Empirics of Agglomeration and Trade,” Chapter 59 in V. Henderson and J.F. Thisse (eds), Handbook of Urban and Regional Economics 4, Elsevier, North Holland.

Head, C.K., J.C. Ries, D.L. Swenson, 1995. "Agglomeration Benefits and Location Choice: Evidence from Japanese Manufacturing Investments in the United States," Journal of International Economics 38(3-4), 223-247.

1999. "Attracting Foreign Manufacturing: Investment Promotion and Agglomeration,” Regional Science and Urban Economics 29(2), 197-218.

Helpman, E., 1998. “The Size of Regions,” in D. Pines, E. Sadka, I. and Zilcha (eds.), Topics in Public Economics, Cambridge University Press, Cambridge. 
Henderson, V.J., 1997. "Externalities and Industrial Development," Journal of Urban Economics 42(3), 449-470.

, 2001. "Urban Scale Economies," in R. Paddison (ed), Handbook of Urban Studies. Sage: London, pp. 243-255.

A. Kuncoro, and M. Turner, 1995. "Industrial Development in Cities," The Journal of Political Economy 103(5), 1067-1090.

Inegi, 1994. Economic Census Mexico 1993. Inegi, Aguascalientes.

, 2004. Sistema de Cuentas Nacioneles de Mexico. La Produccion, Salarios, Empleo y Productividad de la Industria Maquiladora de Exportación. Inegi: Aguascalientes.

Kim, S. 1995. "Expansion of Markets and the Geographic Distribution of Economic Activities: The Trends in U.S. Regional Manufacturing Structure, 1860-1987," The Quarterly Journal of Economics 110(4), 881-908.

Krugman, P., 1991a. Geography and Trade. Louvain University Press, Louvain. , 1991b. "Increasing Returns and Economic Geography,” The Journal of Political Economy 99(3), 483-499.

Krugman, P., and A.J. Venables, 1995. "Globalisation and the Inequality of Nations," The Quarterly Journal of Economics CX(5), 857-880.

Krugman, P., and R.L. Elizondo, 1996. "Trade Policy and the Third World Metropolis," Journal of Development Economics 49(1), 137-150.

Marshall, A., 1890. The Principles of Economics. MacMillan: London.

McDonald, J.F., 1997. Fundamentals of Urban Economics. Prentice-Hall, Inc.

Montfort, P. and R. Nicolini, 2000. "Regional Convergence and International Integration,” Journal of Urban Economics 48, 286-306.

Moomaw, R., 1981. "Productivity and City Size: A Critique of the Evidence," The Quarterly Journal of Economics 96(4), 675-688.

Ohlin, B.G., 1933. Interregional and International Trade. Harvard University Press: Cambridge, MA.

Overman, H., S. Redding, and A.J. Venables, 2001. "The Economic Geography of Trade, Production and Income: A Survey of Empirics," Centre for Economic Performance, London School of Economics and Political Science.

Paluzie, E., 2001. “Trade Policy and Regional Inequalities,” Papers in Regional Science 80(1), 67-85.

Quigley, J.M., 1998. "Urban Diversity and Economic Growth,” Journal of Economic Perspectives 12(2), 127-138.

Romero Kolbeck, G. and V. Urquidi, 1952. La extención Fiscal en el Distrito Federal como Instrumento de Atracción de Industries. Departamento del Distrito Federal: Mexico.

Sachs, J., 2000. “Tropical Underdevelopment,” Centre for International Development, Harvard University, September, Mimeograph.

Sklair, L., 1993. Assembling for Development: The Maquila Industry in Mexico and the United States. Centre for US-Mexican Studies, UCSD, San Diego.

Venables, A.J., 1996. "Equilibrium Location of Vertically Linked Industries," International Economic Review 37(2), 341-359. 